Jurnal Abdimas Berdaya : Jurnal Pembelajaran, Pemberdayaan dan Pengabdian Masyarakat Volume 4 Nomor 01 Tahun 2021

P-ISSN: 2685 - 1563 e-ISSN: 2720 - 9768

\title{
Penyuluhan Pembuatan Laporan Keuangan Usaha Mikro Kecil Dan Menengah
}

\section{Counseling on UMKM Financial Report Making}

\author{
Ratna Ekasari $^{1}$, Varid Martah ${ }^{2}$, Agung Wiranata $^{3}$, Istiqomah $^{4}$, Melandari $^{5}$ \\ 1,2,3,4,5 Universitas Maarif Hasyim Latif \\ e-mail: ${ }^{1}$ ratna_ekasari@dosen.umaha.ac.id
}

\begin{abstract}
Abstrak: Laporan keuangan adalah bagian terpenting dari sebuah bisnis, termasuk UMKM. Salah satu permasalahan yang dihadapi UMKM adalah UMKM yang tidak bankable sehingga membuat UMKM tidak dapat mengajukan kredit untuk kelangsungan usahanya yang sebenarnya sangat dibutuhkan pada saat terjadi pandemi seperti ini. Program ini dilakukan dengan pendampingan kepada UMKM dalam pembuatan laporan keuangan, agar pelaku UMKM menjadi bankable.
\end{abstract}

Kata Kunci: UMKM, Bankable, Laporan keuangan

Abstract: Financial reports are the most important part of a business, including MSMEs. One of the problems that MSMEs have is that MSMEs are not bankable and that makes MSMEs unable to apply for credit for business continuity which is actually very much needed during a pandemic like this. This program is carried out with assistance to MSMEs in making financial reports, so that MSME actors become bankable.

Keywords: UMKM, Bankable, Financial reports

\section{A. Pendahuluan}

Keberadaan UMKM tidak dapat dihapuskan ataupun dihindarkan dari masyarakat bangsa saat ini. Karena keberadaannya sangat bermanfaat dalam hal pendistribusian pendapatan masyarakat. Selain itu juga mampu menciptakan kreatifitas yang sejalan dengan usaha untuk mempertahankan dan mengembangkan unsur-unsur tradisi dan kebudayaan masya-rakat setempat. Pada sisi lain, UMKM mampu menyerap tenaga kerja dalam skala yang besar mengingat jumlah penduduk Indonesia yang besar sehingga hal ini dapat mengurangi tingkat pengangguran. Dari sinilah terlihat bahwa keberadaan UMKM yang bersifat padat karya, menggunakan teknologi yang sederhana dan mudah dipahami mampu menjadi sebuah wadah bagi masyarakat untuk bekerja (www. smecda.com).

Program pengembangan Usaha Mikro, Kecil, dan Menengah (UMKM) sebagai salah satu instrument untuk menaikkan daya beli masyarakat, pada akhirnya akan menjadi katup pengaman dari situasi krisis moneter. Pengembangan UMKM menjadi sangat strategis dalam menggerakkan perekonomian nasional, mengingat kegiatan usahanya mencakup hampir semua 
lapangan usaha sehingga kontribusi UMKM menjadi sangat besar bagi peningkatan pendapatan bagi kelompok masyarakat berpendapatan rendah.

Dusun Bangsri Kecamatan Sukodono merupakan desa yang berpenduduk sekitar 3200 jiwa selalu berbenah dalam bidang pembangunan, baik infra struktur maupun ekstra struktur,yang dibiayai dari dana pemerintah,swadaya warga dan juga dana pribadi dari kepala desa. Disamping pembangunan fisik, peningkatan Sumber Daya Manusia (SDM), pertanian, Usaha Mikro Kecil dan Menengah (UMKM) dan pelayanan prima juga menjadi prioritas untuk dilakukan pengembangan. Bersinergi dengan program desa dalam peningkatan dan pemberdayaan UMKM di Dusun Bangsri, maka kegiatan pengabdian masyarakat ini dilakukan.

Banyak dari pelaku UMKM yang yakin bahwa perusahaannya akan tumbuh dan dapat memperluas pemasaran, namun terkendala dari sisi modal yang terbatas. Bahkan sebagian dari UMKM masih belum tersentuh lembaga keuangan (bank), sehingga banyak juga dari UMKM mengambil jalan untuk memanfaatkan lembaga keuangan mikro walaupun dengan beban dan resiko yang cukup berat.

Kendala utama yang dihadapi pihak UMKM selain modal adalah penerapan manajemen yang profesional. UMKM juga menghadapi keterbatasan modal, rendahnya sumber daya yang ada, serta penguasaan terhadap teknologi dan ilmu pengetahuan sangat rendah (S. Sudaryanto \& Hanim, 2002). dalam sektor keuangan dan pencatatan banyak pengusaha UMKM yang masih tidak memperdulikan pentingnya pencatatan keuangan yang akuntable, sering terjadi dalam UMKM pencatatan keuangan usaha masih bercampur dengan keuangan pribadi, padahal laporan keuangan sangat diperlukan untuk mengurus perizinan dan juga kewajiban pembayaran pajak setelah perizinan yang dapat dilihat dari pencatatan laporan keuangan yang akuntable.

Kegiatan pengabdian masyarakat dalam rangka meningkatkan kemampuan enterpreneur yang dilaksanakan di Dusun Bangsri diharapkan mampu meningkatkan daya saing UMKM di pasar lokal maupun nasional dalam rangka peningkatan perekonomian kerakyatan.

\section{B. Metode}

Kegiatan pengabdian ini dilaksanakan di Dusun Bangsri kecamatan Sukodono, kabupaten Sidoarjo dengan melakukan pemilihan mintra sebagai target atau sasaran progam kegiatan pengabdian masyarakat.

Dengan melakukan pengamatan wawancara dan praktik pembuatan laporan keuagan sesuai tahap-tahap nya. digunakan sebagai perencanaan yang lebih matang sehingga monitoring kepada pelaku usaha lebih maksimal. Pelatihan juga dilakukan terkait pengelolaan keuangan dan cara pembukuan secara sederhana. 


\section{Hasil dan Pembahasan}

Kegiatan penyuluhan dan edukasi pembuatan laporan keuangan ini meliputi penulisan transaksi, penggolongan transaksi hingga pembuatan laporan keuangan. Foto kegiatan dapat dilihat di gambar 1 dan gambar 2.

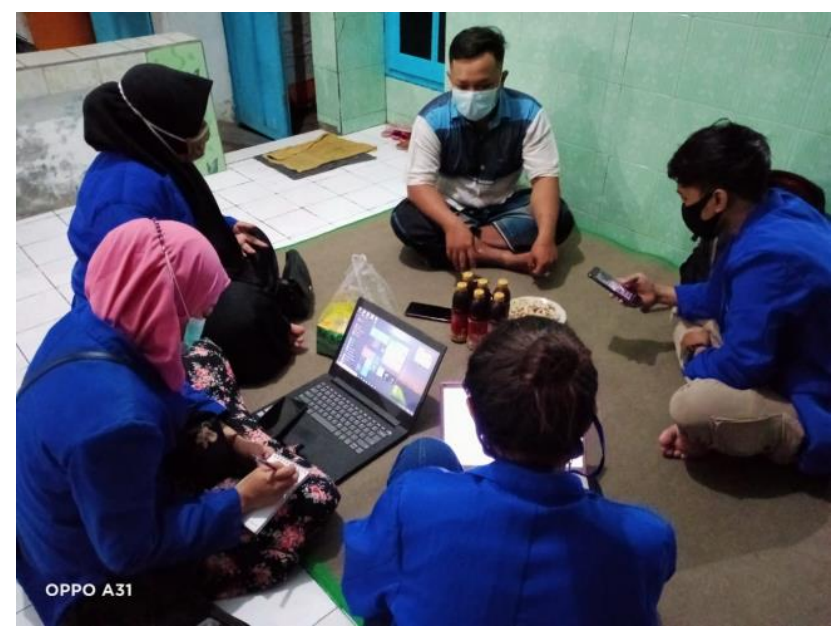

Gambar 1. Wawancara Secara Langsung Terhadap Pelaku Usaha Mikro

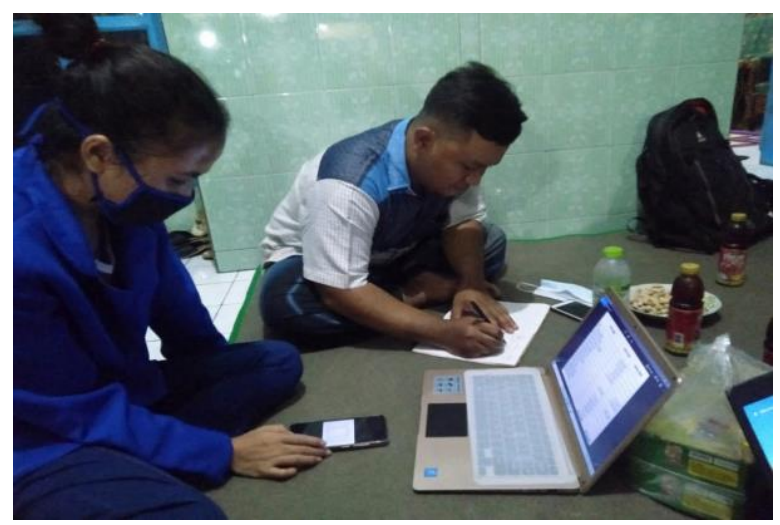

Gambar 2. Pendampingan Pengisian Lembar Kerja Proses Pembuatan Laporan Keuagan Kepada Mitra Selaku Pelaku UMKM

Berdasarkan hasil pengumpulan data terkait jenis UMKM dari pelaku usaha dapat dilihat pada tabel 1 .

Tabel 1. Jenis Barang yang Dijual Perhari

\begin{tabular}{clc}
\hline No. & \multicolumn{1}{c}{ Barang } & $\begin{array}{c}\text { Jual } \\
\text { perhari }\end{array}$ \\
\hline 1 & Air isi ulang & 15 liter \\
2 & Beras & $2-4 \mathrm{~kg}$ \\
3 & Telur & $2-4 \mathrm{~kg}$ \\
4 & Minyak & $3-4$ liter \\
5 & Mie instan & $10 \mathrm{biji}$ \\
\hline
\end{tabular}

JURNAL ABDIMAS BERDAYA: Volume 4 Nomor 01 Tahun 2021 26

Journal Page is available to: https://pemas.unisla.ac.id/index.php/JAB/index 


\begin{tabular}{clc}
\hline No. & \multicolumn{1}{c}{ Barang } & $\begin{array}{c}\text { Jual } \\
\text { perhari }\end{array}$ \\
\hline 6 & Sabun mandi & $3 \mathrm{biji}$ \\
7 & Sabun cuci & $6 \mathrm{biji}$ \\
8 & Gula & $4 \mathrm{~kg}$ \\
9 & Snack & $25 \mathrm{biji}$ \\
10 & Minuman dingin & $5 \mathrm{biji}$ \\
11 & Rokok & 16 \\
& & bungkus \\
\hline
\end{tabular}

Kemudian dilakukan pendataan tentang laba yang dihasilkan, dan belum ada pencatatatan persediaan yang terperinci dimana pemilik melakukan restock kembali saat barang habis, hal ini di akibatkan oleh beberapa alasan seperti belum terpisahnya uang pribadi pemilik dan uang usaaha sehingga belum di ketahui secara pasti apakah usaha yang di lakukan memiliki keuntungan yang telah direncanakan atau tidak. Pendapatan yang dihasilkan oleh usaha UMKM tidak begitu besar, hanya berkisar $2 \mathrm{jt}$-3jt perbulan, belum terpotong oleh pembelian persediaan stock untuk dijual kembali . Pendapatan dan omzet UMKM selama 1 bulan dapat dilihat pada gambar 3.

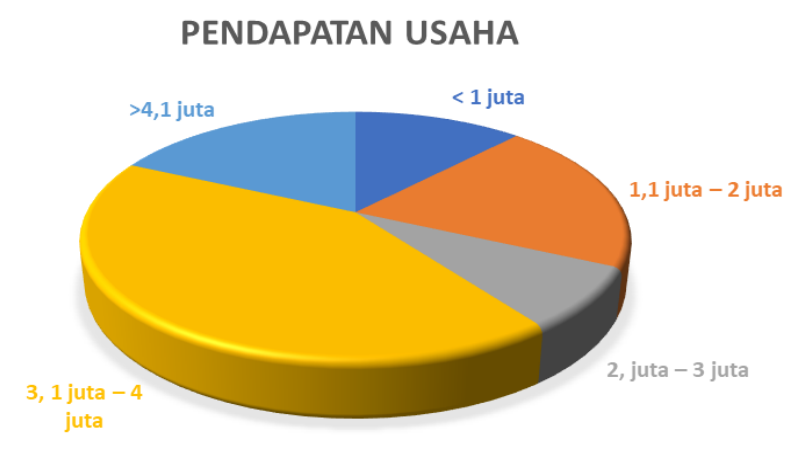

\section{Gambar 3. Pendapatan Usaha UMKM}

Melakukan kegiatan penyuluhan tentang proses pembuatan laporan keuangan untuk Usaha mikro kecil menengah yang melibatkan mitra selaku pelaku usaha. Dalam pelaksanaannya, program ini bekerja sama dengan saudara taufik selaku pemilik dari toko sembako yang berada di Dusun Bangsri RT 01 RW 03 Kecamatan Sukodono. Dari hasil pelaksanan progam ini di dapatkan bahwa proses pencatatan keuangan masih sederhana sehingga dalam perolehan atau penentuan laba masih kurang akurat. Hal ini di akibatkan belum adanya pembuatan laporan keuangan setiap bualannya dan tidak adanya pencatatan persediaan yang terperinci hal tersebut yang mebuat selalu ada selisih saat perhitungan akhir atau saat akan melakukan restock.

Untuk itu di harapkan penyuluhan mengenai pembuatan laporan keuangan untuk UMKM dapat terus di kembangangkan melalui rekomendasi kegiatan yang telah di paparkan sebelumnya sehingga monitoring dalam pengembangan usaha mikro dapat lebih maksimal. 


\section{Simpulan}

Dari hasil kegiatan pengabdian masyarakat di Dusun Bangsri RT 01 RW 03 Kecamatan Sukodono menunjukkan bahwa: 1) Meningkatnya pengetahuan mitra selaku pelaku Usaha mikro menegenai pentingnya pembuatan laporan keuangan dalam UMKM, 2) Meningkatnya ketrampilan dalam pembuatan catatan penjualan sehingga dapat membuat laporan keuangan yang lebih baik, 3) Menambah wawasan kepada mitra selaku pelaku usaha tentang manfaat-manfaat pembukuan dalam menjalankan suatu UMKM. 


\section{Daftar Rujukan}

Hafsah, M. Jafar. (2004) Upaya Pengembangan Usaha Kecil Dan Menengah (UKM). Diakses pada tanggal 3 April 2013 pukul 22.15 WIB dari www.smecda.com.

Islamiyati,nelsi (2017). 5 Permasalahan Utama yang Dihadapi Para Pelaku UMKM https://www.jagoanhosting.com/blog/5-permasalahan-utama-yang-dihadapi-parapelaku-umkm/. Diakses pada tanggal 30 oktober 2017.

Suseno,rahmat (2018). Hambatan dan Kendala UMKM di Indonesia https://www.kompasiana.com/rahmatsuseno01231/5baeedd8bde57543485214a4/h ambatan-dan-kendala-umkm-di-indonesia, Diakses pada tanggal 29 sepember 2018.

Sudaryanto, S., \& Hanim, A. (2002). Evaluasi kesiapan UKM menyongsong pasar bebas ASEAN (AFTA): Analisis perspektif dan tinjauan teoritis. Jurnal Ekonomi Akuntansi Manajemen, 1(2). 